mena, problems and procedures with which Herschel was concerned are described, his researches and discoveries are examined and his contributions to astronomy are assessed and placed in their historical context.

Sir Edward Bailey's splendid little book on Charles Lyell is very readable and is doubly welcome because historians of science have unjustifiably tended to neglect the great geologists. Among other things the book is a good and even exciting travel story. Sir Edward shows with great clarity and some delightful light touches how Lyell gained a wide and varied personal knowledge of the features of the landscape of Britain, Europe and North America, and was thus able "to originate just and comprehensive views concerning the structure of this globe". Lyell's chief work, the Principles of Geology, practically vanquished all those geologists who believe that changes in the Earth's surface had been brought about by tremendous catastrophes involving the wholesale destruction of the landscape.

The general editor of the series of monographs is Sir Gavin de Beer.

W. L. SUMNER

\section{IN HONOUR OF SPINOZA}

Creation, Emanation and Salvation

A Spinozistic Study. By Prof. H. F. Hallett. Pp. xi+234. (The Hague: Martinus Nijhoff, 1962.) 25 guilders.

Spinoza, Dreihundert Jahre Ewigkeit

Spinoza-Festschrift, 1632-1932. Herausgegeben von Siegfried Hessing. 2 vermehrte auflage. Pp. xliii + 205. (Den Haag: Martinus Nijhoff, 1962.) 25 guilders.

T might be incorrect to describe these two scholarly books as in praise of Benedictus de (or Baruch) Spinoza (1632-77), but they are assuredly in his honour. The authors accomplish their tasks as leading authorities in this field of philosophy, and that means presenting their readers with an assessment of Spinoza's genius in the light of twentiethcentury criticism and historical method. To the possible query whether we have not enough commentaries already in this particular branch of learn. ing, the writers might well reply that one can never delve too deeply into the great themes of human experience-life, morals, death-and more especially in an age wherein a materialistic outlook is widespread. Furthermore, it is worth more than mere formal recollection that Spinoza, alone porhaps with Plotinus, achieved a purity of the concept of truth unequalled in their day, and probably never exceeded in any subsequent period. Scientists reading these two volumes, or for that matter either of them, may care to be reminded that Spinoza's doctrine of truth finds due applications in parts of morphology, which is nowhere better displayed than in the writings of the late Dr. Agnos Arber. To have her observations by one's side in reading the pages of these recent publications is to add pleasure to pleasure.

Prof. H. F. Hallett's work, Creation, Emanation and Salvation, is, he tells us, a Spinozistic study, as indeed was his earlier Aeternitatis. After two sections of prolegomena come Part I, "Nature", and Part 2, "Morality", followed by three indexes: (i) References to the works of Spinoza; (ii) Personal names; (iii) Subjects and catchwords. In view of certain contemporary and plausible attempts to limit (in some cases severely) the objectivity of empirical data, the remark that "man is not an extrinsic spectator of nature" is of supreme moment. This is indeed the human predicament, from which it follows that metaphysics has the paramount aim of making sure that error does not creep in as a result of this vital involvement. One can infer from this that our ratiocination must be clothed with humility, if only to avoid the gross mistake of imagining that research can stand, as it were, on the touchline, and watch with bland unconcern what is going on even in the very plane of diseourse which the intellect is striving to comprehend. Or, in the manner of the Psalmist, there is for us no super flumina; it is always de profundis, whether we like it or not.

The present approach to the central problem is activistic, and this in its turn conditions the author's speculations, both ethical and political. It is well known that Spinoza used the geometrical method; yet it was not essentially by means of it that he produced a truth-doctrine akin to the German Wahrheit, or at least one that would support a degree of veracity beyond that which the natural scientist can reach in any purely experimental environment. For Spinoza demands an idea which is, in effect, self-certifying.

Prof. Hallett, in discussing morality and salvation, touches on the relationship between man and his tools, or materials; in fact, his position as a craftsman. Thus, technique is a kind of morality. Every. body who deals with substances knows that to do violence to his clay is no part of a sympathetic, let alone an accomplished, potter. Here, our author is almost in the tradition of John Ruskin: the point is made with a delicate touch which is wholly convincing. A portrait of Spinoza on scraper-board by the author provides an appropriate frontispiece.

Spinoza: Dreihundert Jahre Ewigkeit is in the nature of a dedicatory collection of essays in memory of the period 1632-1932. As one would expect, the emphasis is on the aspect of eternity. The present edition, with the help of additional distinguished authors, has emerged triumphant from the trials and frustrations of the original version of 1933. One can only marvel that from the Germany of that year anything of cultural value should have survived. In itself, it is an example of the indestructibility of truth, and how significant it is that its focal point should have been Spinoza.

The series starts with a salute by the editor; the other members cover most facets of this remarkable life. As an example, there are five scenes, depicted by Franz Droop. These are: (i) a room in Spinoza's house at Amsterdam; (ii) in a near-by street; (iii) in a tavern; (iv) in the Synagogue, on July 27, 1656, the day of his "excommunication"; (v) in his study at The Hague, the year of his death. These are typical conversation-pieces, redolent of seventeenth-century Holland. Other essays deal with Spinoza's political theory, his biblical criticism, the basic dualism of his system, and so forth. The book ends with three short "remarks" by Einstein, Froud and Wassermann, all testifying to the qualities of mind which make Spinoza stand out as a philosopher for all time. His three-fold structure of knowledge-intuitiva, ratio, imaginatio--is secure as one of the treasures of the human race.

F. I. G. Rawlins 